\title{
Organizations Matter: They are Institutions, after All
}

John Linarelli

Touro Law Center, jlinarelli@tourolaw.edu

Follow this and additional works at: https://digitalcommons.tourolaw.edu/scholarlyworks

Part of the Banking and Finance Law Commons, Civil Law Commons, Contracts Commons, and the Law and Economics Commons

\section{Recommended Citation}

6 J. INSTITUTIONAL ECON. 83

This Article is brought to you for free and open access by the Faculty Scholarship at Digital Commons @ Touro Law Center. It has been accepted for inclusion in Scholarly Works by an authorized administrator of Digital Commons @ Touro Law Center. For more information, please contact Iross@tourolaw.edu. 


\title{
Organizations matter: they are institutions, after all
}

\author{
JOHN LINARELLI* \\ University of La Verne College of Law, Ontario California, United States
}

\begin{abstract}
Judge Posner (2010) offers a substantial agenda for organization economics. He advises us on how organization economics can shed substantial light on some of the most pressing social problems of the day. I comment on two of the areas he selects for discussion and offer some comments on the relationship of organization economics to new institutional economics. Judge Posner surely is right to argue that organization economics can help us understand the failures of corporate governance in regulating executive pay. Moreover, with additional and more institutionally nuanced theorizing, organizational economics should further our understanding of the work of judiciaries in the civilian and common law traditions. Judge Posner tells us that organization economics and new institutional economics are related fields. I make a plea for economic holism. Organizations are institutions. While getting clear on disciplinary boundaries and the differing kinds and concepts of institutions is important, logical differences in concepts like 'organization' and 'institution' may be less important than what to emphasize in theory construction and what to test for with those theories. The success of organization economics will be in whether the different emphases produce new insights. Judge Posner is right to tell us that new insights are coming and will continue to come from organization economics. This is true however we conceptualize the field as a school of thought.
\end{abstract}

'We are all legal realists now' is a common saying in the American legal academy, used to refer to the idea that the American legal realists changed the way we inquire about law, going beyond the formal, and to include the social, the political, and the historical. Intellectual leaders of the generation succeeding the legal realists, Judge Posner one of the most influential among them, brought about a second revolution in the legal academy, one with economic analysis at its core. Judge Posner's work has been instrumental in changing the way we think about the law. His canonical text, Economic Analysis of Law, now in its seventh edition, is probably one of the most important books on law in the English language in the twentieth century (Posner, 2007). Economic analysis has profoundly influenced the structure of legal thought, at least in the United States.

*Email: jlinarelli@laverne.edu.

I am grateful for helpful comments from James Hackney. All errors are mine. 
One can find that influence in many casebooks in American law schools. Judge Posner's more recent writings advance us to a pragmatic way of understanding law, but still informed by economics (Hackney, 2007; Posner, 1999, 2001).

In his article for this journal, Judge Posner (2010) continues his pragmatic enterprise by informing us that organization economics has the potential to further our understanding of organizations of relevance to law and that focusing organization economics on law-related organizations will blend organizational economics into economic analysis of law. He also identifies connections between organization economics and new institutional economics, or between 'OE' and 'NIE', as they are sometimes referred to in this essay. In sum, and to adapt a phrase originating in NIE, Judge Posner tells us that 'organizations matter'.

I make three sets of points, two substantive and one methodological. Starting with the substantive points, Judge Posner makes an important contribution to the discussion of excess corporate compensation. More research along the lines he suggests, and more importantly, a following up with legal reform along the lines suggested by that research, is one of the more important corporate governance projects we face in the coming years. Second, organization economics might be able to assist in comparative examinations of common law and civilian judiciaries, but I believe that additional theory construction is necessary in that area. The work on judiciaries leads to my methodological points, which summarize into a worry about too much compartmentalization in economics and skepticism about whether NIE and OE sharply demarcate.

\section{Excess executive compensation}

Judge Posner describes a dismal state of affairs for corporate governance, at least in the United States and in other countries with capital markets in which share ownership is dispersed. Shareholders often have few incentives to monitor because of free rider problems. If they are dissatisfied with the firm's performance, they can sell their shares rather than engage in costly monitoring. Product and capital markets are overrated as controls on agency costs. Various commitment devices for monitoring and keeping managers accountable in the nonprofit sector are not feasible in for-profit firms. CEO performance is difficult to evaluate. Dispersed share ownership means that directors have poor incentives to monitor on behalf of shareholders. Directors are often highly paid executives themselves and tend to accept the notion that significant compensation packages for CEOs and other senior management are warranted. Outside directors are part-timers and devote too little time to the firm, while inside directors have a structural or positional conflict of interest. The CEO has significant influence over selection of both insider and outside board members, hires and pays auditors, and steers underwriting fees to securities analysts. Boards are captured by the so-called IBM effect; they believe that paying top dollar for the top dog means they are getting top quality. Consulting firms hired by the compensation committees of boards of directors 
confirm these beliefs. CEO candidates, knowing the game, demand significant compensation as a signal of their quality. The board's selection of a CEO is the acceptance of the CEO's business strategy; when the board and the CEO disagree on strategic issues, it is a signal that a new CEO may be required. Boards fail to tie stock compensation to performance. The practice until recently of not expensing compensation in the form of stock options supports doubts about the efficiency of capital markets. Stock option compensation gives managers incentives to take too much risk because their loss downside is capped at the value of the stock options but their upside is unbounded. Boards of directors approve a number of questionable compensation packages, such as golden parachutes, on the basis of questionable rationales. And so on.

These pathologies of corporate governance that Judge Posner identifies may not direct us inexorably towards OE theories or techniques for understanding them, but they do tell us that when share ownership is dispersed, and monitoring by shareholders is costly, the board of directors as an organization needs to be radically rethought and restructured. Others have used economic analysis to reach similar results. But Judge Posner directs our attention more directly to facts about organizations that matter.

Here is a way to understand OE's connection to standard versions of economic analysis of corporate law. Fiduciary duties are of doubtful effectiveness for monitoring directors, but their enforcement by courts could be seen as one of several monitoring devices. These legal standards, if effectively enforced, should affect the composition and action of the board as an organization. If what Judge Posner says is true, boards of directors in the United States and elsewhere are currently governed by legal standards that are wholly inadequate to the task of maximizing shareholder wealth or the interests of any constituency other than management. US and British courts generally presume that board decisions are entitled to the presumption of the business judgment rule, which is that the directors acted on an informed basis, in good faith, and with the honest belief that the decision was taken in the company's best interests. Courts will not second-guess board decisions but look primarily at the adequacy of the decisionmaking process. Courts will review the merits of board decisions under duty of loyalty standards when board members have a conflict of interest, but conflicts of interest are defined very narrowly to be conflicts between corporate interests and the financial or private interests of board members, such as when directors are on both sides of a transaction - a set of circumstances that are very rare for publicly held companies. Structural conflicts do not count, except possibly as in the narrow exception Delaware has carved out for special litigation committees in demand excused cases in derivative action litigation. ${ }^{1}$ So, in the US and likely

1 In Re Oracle Corp. Derivative Litigation, 824 A.2d 917 (Del. Ch. 2003). It is arguable that structural conflicts do matter to some extent in judicial review of takeover defenses in US courts, but that subject is beyond our scope here. See, e.g., Unocal Corp. v. Mesa Petroleum Co., 493 A.2d 946 (Del. 1985). 
elsewhere, the structural conflicts of interest Judge Posner identifies have no legal significance. Fiduciary duties provide weak incentives for a board to act in the interests of shareholders. Connect these defects in substantive law with the costliness of shareholder derivative litigation, along with the failure of capital and product markets to discipline the market for managers, and we get the familiar results. It is an interesting result to say that $\mathrm{OE}$ might tell us to substantially strengthen fiduciary duties so as to more closely align director and shareholder interests, because it also means that the move to making fiduciary duties default rules, suggested by some neoclassical law and economics scholars, is precisely the wrong argument to make (Easterbrook and Fischel, 1991; Bainbridge, 2008).

Judge Posner is in the forefront of controversies in the courts about the scope of fiduciary duties. In Jones v. Harris Associates L.P., mutual fund investors sued an investment adviser for breach of fiduciary duty in charging allegedly excessive fees to manage the funds. ${ }^{2}$ The US Investment Company Act of 1940, as amended in 1970, imposes fiduciary duties on investment advisers relating to compensation for their services. ${ }^{3}$ In Gartenberg v. Merrill Lynch Asset Management, the Second Circuit Court of Appeals held that an investment adviser violates the fiduciary duty if her fee 'bears no relationship to the services rendered and could not have been the product of arm's-length bargaining'. ${ }^{4}$ Gartenberg holds that judges can determine whether investment advisor fees are excessive. In Jones, the Seventh Circuit Court of Appeals, in an opinion written by Judge Frank Easterbrook, explicitly disapproved of Gartenberg and held that fiduciary duties require full disclosure and that investment advisors 'play no tricks' but that a judicial evaluation of fees goes too far because efficient capital markets and competition in the investment industry effectively regulate fees. ${ }^{5}$ Judge Posner did not sit on the panel for the case but wrote the dissent in the denial of a motion for a rehearing en banc. In his dissent, he criticized Judge Easterbrook's majority opinion as based on 'an economic analysis that is ripe for reexamination on the basis of the growing indications that executive compensation in large publicly traded firms often is excessive because of the feeble incentives of boards of directors to police compensation' ${ }^{6}$ He further explained that 'competition in the product and capital markets can't be counted on to solve the problem because the same structure of incentives operates on all large corporations and similar entities, including mutual funds. Mutual funds are a component of the financial services industry, where abuses have been rampant. ${ }^{, 7}$ The Supreme Court has granted certiorari in the case.

2 Jones v. Harris Associates L.P., 527 F.3d 627 (7th Cir. 2008).

315 U.S.C. $\S 80 a-35 b$.

4 Gartenberg v. Merrill Lynch Asset Management, Inc., 694 F.2d 923, 928 (2d Cir. 1982).

5 Jones, 527 F.3d at 632.

6 Jones v. Harris Associates, L.P., 537 F.2d 728, 730 (7th Cir. 2008).

7 Ibid. 
Judge Posner's account has special relevance in these times of economic crisis. The AIG bonus controversy, though exaggerated in significance by the media, is a recent example of the failure of corporate governance. AIG could not survive without billions of dollars of bailout funds from the US federal government. Regardless of whether AIG management bears any responsibility for the failure of the company or the financial crisis, it is a firm in severe financial distress and in no position to pay out over \$1 billion in bonuses. Yet the AIG CEO testified before the US Congress that the law obligates AIG to 'honor its contracts' and the Obama Administration ended up agreeing with this assessment. If indeed it is not a breach of fiduciary duty for a board to approve contracts that pay guaranteed compensation regardless of the financial status of the firm, then the law fails to provide boards with the proper incentives. It is common for other types of contracts, such as loans and employment contracts for mid-level employees, to contain conditions excusing performance in the event of financial exigency. AIG managers have more protection than university professors, whose tenure is subject to financial exigency conditions and who forego high levels of compensation for job security, autonomy, and reputational rewards.

The existing economic toolkit might help us to understand these problems and to devise prescriptions. OE's merits are perhaps in its focus on the board as an organization and that focus may shed new light on corporate law's failures to provide incentives for corporations to develop organizational structures responsive to shareholder interests. Judge Posner says that $\mathrm{OE}$ and economic analysis of law may blend together. The above discussion is at least a partial attempt to show how the two specializations connect. Fiduciary duties tell us a great deal about how boards of directors function as organizations. If, for example, courts were to expand fiduciary duties to regulate structural conflicts of interest and effectively enforced such duties in shareholder litigation that actually benefits shareholders, we might see very different board compositions and decisions. But OE might likely confirm for us that courts and fiduciary duties can be ineffective in aligning shareholder and management interests and that ex ante regulation might be necessary. Here we can turn the question around and ask which organization, or mix of organizations, are better regulators, the Delaware judiciary and legislature, Congress and the SEC, or a mix of some or all?

\section{Comparing common law and civilian judiciaries}

Judge Posner's insight that OE has a role in understanding differences in career judiciaries in civilian legal systems versus status judiciaries in common law systems has the potential to open the scope of inquiry in the growing field of the economics of comparative law or comparative law and economics. NIE has made inroads in that field (Mattei, 1997). Judge Posner advises that it is now time for OE to have a role. 
The distinction between career and status judiciaries is a significant one with deep historical roots. Stripped of its historical narrative and recast as a principalagent problem, the question is one of control of the judiciary, the agent, by the legislature, the principal, with the ultimate principal being the citizens. Judge Posner says that civilian judiciaries function like any other public bureaucracy and that 'an essential control mechanism in public bureaucracies ... is clear rules to guide employees'. He further states that in civilian legal systems, 'detailed legal codes reduce judicial discretion by enabling and directing the judges to decide the vast majority of cases by a simple comparison of the text of the applicable code with the facts of the case', that 'career judiciaries tend to be found in legal systems that rely heavily on detailed codes rather than on looser standards that are characteristic of common law systems', and that the decision to have a career judiciary may lead to the adoption of detailed codes. He also says that 'America's undisciplined legislatures can rarely produce legal codes that are sufficiently clear and detailed to minimize judicial discretion', which makes status judiciaries better in a common law jurisdictions like the United States.

It is doubtful that the codes found in civil law systems are doing the work of controlling the judiciary as Judge Posner suggests, but he is right to argue that $\mathrm{OE}$ has something to offer in the analysis of judiciaries. Civilian codes are far from detailed. For example, French courts have interpreted Articles 1381 through 1384 of the French Civil Code to form the basis of the French law of obligations in what we would know as tort law in the common law tradition (Gordley, 2006; Merryman and Perez-Perdoma, 2007). These provisions are vague or empty to American lawyers, in the form of what we would know as general principles or precepts. They use words such as 'harm' and 'fault', but do not define them, leaving French courts to decide their meaning. French courts have declared Article 1384 to be the source for strict liability, even though the relevant language of that article, written in the early nineteenth century, says nothing about strict liability without some serious interpretive work.

What infuses these provisions with meaning and acceptable levels of certainty is not the level of detail in their language. Rather, in OE terms, it is the professional culture in the civilian legal system that likely provides the controls Judge Posner seeks to explain. Code provisions seem empty to American lawyers because we do not participate in the 'code' of the civilian professional culture. The civilian system of legal education inculcates legal professionals into the 'science' of law, built in a cathedral-like manner from the ground up in code and in the commentaries written by academics. Civilian lawyers and judges use the codes, the commentaries, and other materials to acquire an understanding of doctrine. The codes in this system are supposed to be complete, systematic, and rational statements of the law and judges are supposed to apply but not interpret their provisions, or at least not use grammatical methods of interpretation. Whether this professional culture actually controls career judiciaries is debatable. While the 'image' of the civilian judge is that of 
the automaton who mechanistically uses the syllogism to decide cases, that is widely understood to be a mischaracterization (MacLean, 1982).

So far all that has been said is not yet at the level of testable theory. But there are plenty of facts about organizations from which to start the work of theory construction. Whether an $\mathrm{OE}$ focus results in new insights remains to be seen.

\section{A plea for economic holism}

The distinction between NIE and OE may beg a question. Are there real differences between them, or are they both simply part of a more broadly conceptualized tradition in institutionally informed economics? What is the difference between an organization and an institution? Going back to the very first article published in the Journal of Institutional Economics, we find John Searle's description of an institution as a social practice assigning a status to a person or thing to do something it could not do solely by virtue of its physical structure (Searle, 2005). His description includes organizations. Douglass North's definition of an institution could be said to include organizations (Hodgson, 2006). Geoffrey Hodgson makes clear distinctions but defines an organization to be a special sort of institution. He defines 'institutions' as 'systems of established and embedded social rules that structure social interactions' and 'organizations' as 'special institutions that involve (a) criteria to establish their boundaries and to distinguish their members from nonmembers, (b) principles of sovereignty concerning who is in charge, and (c) chains of command delineating responsibilities within the organization' (Hodgson, 2006). The internal aspects of many organizations seem to depend at least partly for their existence and structure on institutions. For example, the composition of the corporate board of directors depends on legal rules, stock exchange listing standards, and social norms. Similar points can be made about national security agencies such as Homeland Security, the CIA, and the FBI, and judiciaries in both civilian and common law jurisdictions.

Contemporary economics thrives on compartmentalization into schools of thought. Do these schools of thought matter in the search for truth? Theory construction might be more a matter of emphasis than of strict demarcations based on logical differences in concepts like 'organization' and 'institution'. The question of emphasis in theory construction may make a difference in shedding new light on old problems. OE might be said to focus on the internal aspects of organizations, while NIE on socio-economic aspects (Hodgson, 2006). In sum, organizations matter; they are institutions after all.

\section{References}

Bainbridge, S. M. (2008), The New Corporate Governance in Theory and Practice, Oxford: Oxford University Press. 
Easterbrook, F. H. and D. R. Fischel (1991), The Economic Structure of Corporate Law, Cambridge, MA: Harvard University Press.

Gordley, J. (2006), Foundations of Private Law: Property, Tort, and Unjust Enrichment, Oxford: Oxford University Press.

Hackney, J. (2007), Under Cover of Science: American Legal-Economic Theory and the Question for Objectivity, Durham, NC: Duke University Press.

Hodgson, G. M. (2006), 'What are institutions?', Journal of Economic Issues, 40: 1-25.

MacLean, R. G. (1982), 'Judicial discretion in the civil law', Lonisiana Law Review, 43: 45-56.

Macy, J. R. (2008), Corporate Governance: Promises Kept, Promises Broken, Princeton, NJ: Princeton University Press.

Mattei, U. (1997), Comparative Law and Economics, Ann Arbor: University of Michigan Press.

Merryman, J. H. and R. Perez-Perdomo (2007), The Civil Law Tradition; An Introduction to the Legal Systems or Europe and Latin America, 3rd edn, Palo Alto: Stanford University Press.

Posner, R. A. (1999), Overcoming Law, Cambridge, MA: Harvard University Press.

Posner, R. A. (2001), Frontiers of Legal Theory, Cambridge, MA: Harvard University Press.

Posner, R. A. (2007), Economic Analysis of Law, 7th edn, New York: Aspen.

Posner, Richard A. (2010), 'From the new institutional economics to organization economics: with applications to corporate governance, government agencies, and legal institutions', Journal of Institutional Economics, 6(1): 1-37.

Searle, J. (2005), 'What is an institution?', Journal of Institutional Economics, 1: 1-22. 